\section{Ammonium and Nitrate Uptake throughout Development in Dendranthema $\times$ grandiflorum}

\author{
Joseph J. King1, Lloyd A. Peterson ${ }^{2}$, and Dennis P. Stimart ${ }^{2}$ \\ Department of Horticulture, University of Wisconsin, Madison, WI 53706
}

Additional index words. chrysanthemum, $\mathrm{N}$ nutrition, nutrient efficiency

\begin{abstract}
Ammonium and $\mathrm{NO}_{3}$ uptake from hydroponic solutions containing 1 mм each of $\left(\mathrm{NH}_{4}\right)_{2} \mathrm{SO}_{4}$ and $\mathrm{Ca}\left(\mathrm{NO}_{3}\right)_{2}$ were measured during development of Dendranthema $\times$ grandiflorum (Ramat.) Kitamura 'Iridon', 'Sequoia', and 'Sequest'. Nitrogen depletion from solutions approximated a $1 \mathrm{NH}_{4}: 1 \mathrm{NO}_{3}$ ratio throughout a 90-day growth cycle $(\mathrm{r}=$ 0.96). Although harvest date $\times$ cultivar interactions were significant for both forms of $N$, overall patterns of $\mathbf{N}$ uptake were similar among cultivars. Nitrogen removal from hydroponic solutions (milligrams per plant) was greatest from days 40 to 60; however, $N$ removal (milligrams per gram of tissue dry weight) was greatest in the first month of development and decreased steadily until day 90 . From day 40 to 60 , new leaf development ceased while inflorescence buds developed to $\approx 1.0 \mathrm{~cm}$ in diameter. After this time, $\mathrm{N}$ uptake decreased rapidly as inflorescences expanded. Correlations between morphological changes and $\mathbf{N}$ demand could maximize the efficiency of applied $\mathbf{N}$ by matching form and application timing with plant needs.
\end{abstract}

Nitrogen requirements of potted Dendranthema $\times$ grandiflorum are known to be highest during the first 7 weeks of growth, and during this time, deficiencies are difficult to correct in later stages of development (Lunt and Kofranek, 1958). Tissue $\mathrm{N}$ accumulation was rapid in median leaves of 'Bonnaffon Deluxe' chrysanthemum during weeks 1 to 4 , after which $\mathrm{N}$ accumulation stabilized or decreased (Boodley and Meyer, 1965). The N accumulation rate in aboveground vegetative tissues of 'GT4 Indianapolis White' decreased after week 6 of growth, and $\mathrm{N}$ was lost from stems and petioles between weeks 6 and 9 (Woodson and Boodley, 1983). From week 1 through 7 , a slight but steady decrease in relative $\mathrm{N}$ accumulation rate (grams $\mathrm{N}$ accumulated per gram $\mathrm{N}$ in plant per day) was observed in 'Fiesta' chrysanthemums (Willits et al., 1992). Nitrate accumulation in roots of 'GT4 Indianapolis White' occurred at nearly constant rates throughout plant development when $\mathrm{NO}_{3}$ was supplied at 3.75 or $15.0 \mathrm{~mm}$ (Woodson et al., 1984).

To maximize the quality of chrysanthemum crops, reduction or termination of $\mathrm{N}$ applications is recommended when inflorescence bud diameters are 1.0 to $1.5 \mathrm{~cm}$ (Lunt and Kofranek, 1958). Continued fertilization after this stage caused distorted and brittle foliage (Kofranek, 1992) and diminished post-

Received for publication 2 Sept. 1994. Accepted for publication 29 Dec. 1995. Use of trade names does not imply endorsement of the products named nor criticism of similar ones not named. We gratefully acknowledge the gift of plant materials from Yoder Brothers, Barberton, Ohio. The cost of publishing this paper was defrayed in part by the payment of page charges. Under postal regulations, this paper therefore must be hereby marked advertisement solely to indicate this fact.

${ }^{1}$ Graduate Research Assistant.

${ }^{2}$ Professor. harvest quality (Nell et al., 1989). Declining requirements for $\mathrm{N}$ after flower initiation are attributed to $\mathrm{N}$ remobilization from vegetative tissues supporting latter stages of inflorescence development (Woodson and Boodley, 1983).

Growth of chrysanthemum was improved with $\mathrm{N}$ supplied as combinations of $\mathrm{NH}_{4}$ and $\mathrm{NO}_{3}$, rather than as $\mathrm{NO}_{3}$ alone (Elliott and Nelson, 1983). Some nutritional studies with chrysanthemum used flowing (Elliott and Nelson, 1983) or static (Willits et al., 1992) hydroponic solutions, but most researchers have used sand media with solutions of known concentration and volume added at regular intervals. The nature of the sand-media experiments prevented observation of forms and quantities of $\mathrm{N}$ removed from solutions during plant development. The purposes of our research were to 1) determine quantities of $\mathrm{NH}_{4}$ and $\mathrm{NO}_{3}$ removed from nutrient solutions during vegetative and reproductive stages of chrysanthemum development, 2) further examine if morphological changes could be used as indicators of changing $\mathrm{N}$ demands, and 3) cultivar interaction was not significant. compare $\mathrm{N}$ requirements of three cultivars as a preliminary evaluation of genetic effects on $\mathrm{N}$ demands.

\section{Materials and Methods}

We used unrooted cuttings of Dendranthema $\times$ grandiflorum 'Iridon', 'Sequoia', and 'Sequest'. These cultivars are pottype chrysanthemums with 'Iridon' in the 9week flowering response group and 'Sequoia' and 'Sequest' in the 10-week group. 'Sequest' is a yellow-flowered sport of the bronze-flowered 'Sequoia'. Cuttings were stuck into sterile vermiculite and placed under a deionizedwater misting system until adventitious roots were visible. Plants were transferred to round, black polyethylene greenhouse pots with drainage holes sealed with tape to eliminate light. Containers were lined with clear polyethylene bags, then filled with Hoagland's solution (Hoagland and Arnon, 1950) containing $1 \mathrm{~mm}$ each of $\left(\mathrm{NH}_{4}\right)_{2} \mathrm{SO}_{4}$ and $\mathrm{Ca}\left(\mathrm{NO}_{3}\right)_{2}$. Each container was covered with a square 2.5 -cm-thick piece of extruded polystyrene insulation with a recessed circular groove cut to the diameter and wall thickness of the container. This arrangement allowed a tight seal between the container and lid to eliminate light penetration and moisture loss. One $4-\mathrm{cm}$ hole bored into each lid allowed for placement of a rooted cutting into the nutrient solution. Pieces of foam sealed the holes around plant stems. Aeration was provided to the solution in each container. Solution $\mathrm{pH}$ was adjusted to 5.6 every $48 \mathrm{~h}$, and deionized water was added to maintain solution volume throughout the experiment. Sixteen-liter stock containers held four plants for future sampling periods, one of each cultivar and one selected randomly from the cultivars. Four-liter sampling containers held single plants and were arranged in a randomized complete block, with four blocks and one plant per cultivar per block. Nutrient solution and plant samplings were from these 4-liter containers. In both container types, available $\mathrm{N}$ was $112 \mathrm{mg}$ each of $\mathrm{NH}_{4}$ and $\mathrm{NO}_{3}$ $\mathrm{N}$ per plant. The experiment was conducted in a glasshouse where light levels were maintained at $\geq 550 \mu \mathrm{mol} \cdot \mathrm{m}^{-2} \cdot \mathrm{s}^{-1}$ with 1000 -W, highpressure sodium lamps. From day 1 (22 Feb.), when rooted cuttings were placed into nutrient solutions, through day 17 (10 Mar.), the pho-

Table 1. Harvest date and cultivar effects on $\mathrm{NH}_{4}$ and $\mathrm{NO}_{3}$ removal from hydroponic solutions. Mean squares for linear, quadratic, and cubic polynomials are presented for harvest date only if the harvest date $\times$

\begin{tabular}{|c|c|c|c|c|}
\hline \multirow{3}{*}{$\begin{array}{l}\text { Source } \\
\text { of variation }\end{array}$} & \multicolumn{4}{|c|}{ Mean squares } \\
\hline & \multicolumn{2}{|c|}{$\mathrm{mg}$} & \multicolumn{2}{|c|}{$\mathrm{mg} / \mathrm{g}$ dry wt } \\
\hline & $\mathrm{NH}_{4}$ & $\mathrm{NO}_{3}$ & $\mathrm{NH}_{4}$ & $\mathrm{NO}_{3}$ \\
\hline Block & $639.9^{* * *}$ & $474.9^{* *}$ & $30.5^{*}$ & $15.0^{*}$ \\
\hline Harvest date (D) & $5208.1^{* *}$ & $4923.0^{* *}$ & $727.7^{* *}$ & $486.7^{* * *}$ \\
\hline Linear & -- & --- & $5463.8^{* *}$ & --- \\
\hline Quadratic & --- & --- & $340.2^{* *}$ & --- \\
\hline Cubic & --- & --- & $2.2^{\mathrm{NS}}$ & --- \\
\hline Cultivar(C) & $1137.9^{* *}$ & $2468.1^{* *}$ & $3.2^{\mathrm{NS}}$ & $3.6^{\mathrm{NS}}$ \\
\hline $\mathrm{D} \times \mathrm{C}$ & $393.2^{* *}$ & $377.4^{* *}$ & $6.8^{\mathrm{NS}}$ & $10.3^{* *}$ \\
\hline Linear & $108.7^{\mathrm{NS}}$ & $92.8^{\mathrm{NS}}$ & --- & $6.0^{\mathrm{NS}}$ \\
\hline Quadratic & $1160.3^{* *}$ & $1652.2^{* *}$ & --- & $42.1^{* *}$ \\
\hline Cubic & $909.6^{* * *}$ & $497.5^{* *}$ & --- & $12.7^{*}$ \\
\hline
\end{tabular}

Ns, **** Nonsignificant or significant at $P \leq 0.05$ or 0.01 , respectively. 
toperiod consisted of natural daylength plus one 4-h night interruption (2200 to $0200 \mathrm{HR}$ ). From day 17 to 90 (May 22), plants were grown under short days by covering with blackcloth from 1700 to 0800 HR. Plants were pinched and then disbudded to two inflorescences. Temperature settings were $17 \mathrm{C}$ minimum/24C maximum.

Plants were harvested from the 4-liter sampling containers every 10 days through day 90 , and solutions were sampled at days 1,5 , and 10 of each cycle. Each new 10-day cycle was initiated by a change of polyethylene bags and solutions, and transferring 12 plants (three cultivars $\times$ four blocks) from 16-liter stock containers to 4-liter sampling containers.

Height and inflorescence diameter were measured and leaves were counted on harvested plants. Root and shoot portions were washed in deionized water, separated, and oven-dried at $60 \mathrm{C}$ for 5 days, after which dry weights were determined. Dried root and shoot tissues were ground in a Wiley mill to pass through a $0.425-\mathrm{mm}$ (40-mesh) screen. Ammonium and $\mathrm{NO}_{3}$ were extracted by treating $250 \mathrm{mg}$ of dried tissue with $100 \mathrm{ml} 2.0 \mathrm{M} \mathrm{KCl}$ for $30 \mathrm{~min}$ on a rotary shaker, then filtering through Whatman no. 1 filter paper. Blanks containing only $\mathrm{KCl}$ solutions were included for background levels of $\mathrm{NH}_{4}$ and $\mathrm{NO}_{3}$. Ammonium and $\mathrm{NO}_{3}$ concentrations of blanks, filtrates from extraction of dried tissues, and hydroponic solutions were determined by micro-Kjeldahl procedures (Keeney and Nelson, 1982), with magnesium oxide as the alkali and Devarda's alloy for $\mathrm{NO}_{3}$ reduction to $\mathrm{NH}_{4}$. Samples were distilled into a boric acidbromocresol green-methyl red indicator solution and titrated with $0.01 \mathrm{~N} \mathrm{H}_{2} \mathrm{SO}_{4}$ to an endpoint determined by appearance of a lightpink pigment. Ammonium and $\mathrm{NO}_{3}$ variables were expressed as milligrams removed from hydroponic solutions and as percentage of tissue dry weights.

Total N was determined for 'Sequoia' tissues by macro-Kjeldahl procedures (Bremmer, 1965) with a permanganate-reduced $\mathrm{Fe}$ modification for recovery of $\mathrm{NO}_{3}-\mathrm{N}$ (Olsen, 1927). A single cultivar was sampled based on similarities of trends observed among the three cultivars for most characteristics studied.

Data were tested by analysis of variance (ANOVA), with blocks, harvest dates, and cultivars as independent variables affecting changes in $\mathrm{N}$ and growth attributes.

\section{Results}

In the ANOVA, harvest date $\times$ cultivar interactions significantly influenced the milligrams of $\mathrm{NH}_{4}$ and $\mathrm{NO}_{3}$ removed from hydroponic solutions, milligrams per gram dry weight of $\mathrm{NO}_{3}$ removed from hydroponic solutions (Table 1), $\mathrm{NO}_{3}$ concentration in roots, and $\mathrm{NH}_{4}$ and $\mathrm{NO}_{3}$ concentrations in shoots (Table 2). Harvest date significantly influenced all $\mathrm{N}$ variables tested (Tables 1 and 2). Cultivar significantly influenced all variables except milligrams per gram dry weight of $\mathrm{NH}_{4}$ and $\mathrm{NO}_{3}$ removed from solutions (Tables 1 and 2).
Table 2. Harvest date and cultivar effects on $\mathrm{NH}_{4}$ and $\mathrm{NO}_{3}$ concentration in root and shoot tissue of Dendranthema $\times$ grandiflorum grown in hydroponic solution. Mean squares for linear, quadratic, and cubic polynomials are presented for harvest date only if the harvest date $\times$ cultivar interaction was not significant.

\begin{tabular}{|c|c|c|c|c|}
\hline \multirow{3}{*}{$\begin{array}{l}\text { Source } \\
\text { of variation }\end{array}$} & \multicolumn{4}{|c|}{ Mean squares } \\
\hline & \multicolumn{2}{|c|}{ Root } & \multicolumn{2}{|c|}{ Shoot } \\
\hline & $\mathrm{NH}_{4}$ & $\overline{\mathrm{NO}_{3}}$ & $\mathrm{NH}_{4}$ & $\mathrm{NO}_{3}$ \\
\hline Block & $0.0001^{\mathrm{NS}}$ & $0.051^{* *}$ & $0.001^{*}$ & $0.017^{\mathrm{NS}}$ \\
\hline Harvest date (D) & $0.003^{* *}$ & $0.714^{* *}$ & $0.002^{* * *}$ & $0.090^{* *}$ \\
\hline Linear & $0.000^{\mathrm{NS}}$ & --- & --- & --- \\
\hline Quadratic & $0.013^{* *}$ & --- & --- & --- \\
\hline Cubic & $0.002^{* *}$ & --- & --- & --- \\
\hline Cultivar (C) & $0.012^{* *}$ & $0.287^{* *}$ & $0.023^{* *}$ & $0.553^{* *}$ \\
\hline $\mathrm{D} \times \mathrm{C}$ & $0.0003^{\mathrm{NS}}$ & $0.031^{* * *}$ & $0.0006^{*}$ & $0.028^{* *}$ \\
\hline Linear & --- & $0.046^{*}$ & $0.0005^{\mathrm{NS}}$ & $0.086^{* *}$ \\
\hline Quadratic & --- & $0.031^{\mathrm{NS}}$ & $0.0007^{\mathrm{NS}}$ & $0.069^{* *}$ \\
\hline Cubic & --- & $0.083^{* *}$ & $0.0014^{*}$ & $0.032^{*}$ \\
\hline
\end{tabular}

$\overline{\mathrm{NS}, *, * *}$ Nonsignificant or significant at $P \leq 0.05$ or 0.01 , respectively.
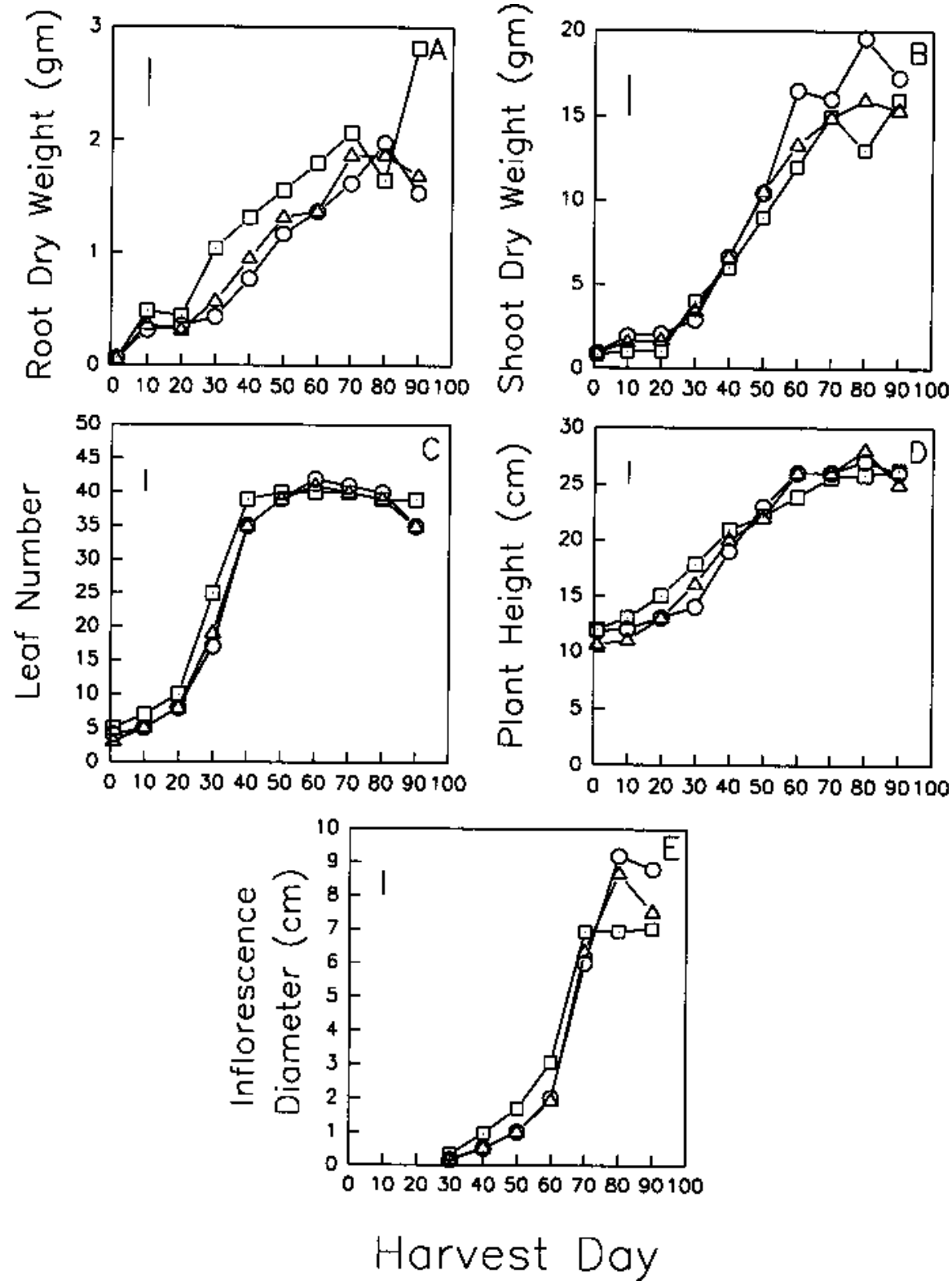

Fig. 1. (A) Root and (B) shoot dry weights, (C) leaf number, (D) plant height, and (E) inflorescence diameter of Dendranthema $\times$ grandiflorum $(\square)$ 'Iridon', (O) 'Sequoia', and $(\Delta)$ 'Sequest' grown in hydroponic solution with $1 \mathrm{~mm}$ each of $\mathrm{NH}_{4}$ and $\mathrm{NO}_{3}-\mathrm{N}$. Vertical bars indicate least significant difference at $P \leq 0.05$. 
Growthfactors. Changes in root dry weight fit a cubic response for the harvest date $x$ cultivar interaction (Fig. 1A). At the final harvest (day 90), root weights were 34 times greater than weights at day 1 . Growth curves for all cultivars approximated sigmoid forms for shoot dry weight, leaf count, plant height, and inflorescence diameter (Fig. 1). For shoot dry weight, leaf count, and plant height (Fig. $1 B-D$ ), a lag phase of $\approx 20$ days was followed by rapid growth until about day 50 for leaf count and day 70 for shoot dry weight and plant height. Inflorescence diameter (Fig. 1E) increased rapidly between days 30 and 70 for 'Iridon' and between days 40 and 80 for 'Sequoia' and 'Sequest'.

Nitrogen removal from solutions. Ammonium and $\mathrm{NO}_{3}$ removal from solutions approximated a $1 \mathrm{NH}_{4}: 1 \mathrm{NO}_{3}$ ratio $(\mathrm{r}=0.96)$ for all cultivars throughout the crop cycle (Fig. 2). There was a significant cubic response for the harvest date $\times$ cultivar interactions for these variables. The period of greatest $\mathrm{N}$ uptake was between days 30 and 60 (Fig. 2 A and B). Uptake was greatest around day 40 for 'Iridon' and 'Sequest' and day 50 for 'Sequoia'. On a tissue dry-weight basis, removal of $\mathrm{NH}_{4}$ and $\mathrm{NO}_{3}$ from solutions was greatest during the first 10 days of the experiment, then declined to nearly zero by day 90 (Fig. $2 \mathrm{C}$ and D). Ammonium removal fit a quadratic pattern over harvest dates, and $\mathrm{NO}_{3}$ removal fit a cubic pattern for harvest date $\times$ cultivar.

Amounts of $\mathrm{NH}_{4}$ and $\mathrm{NO}_{3}$ removed from solutions during the first and second 5 days of each 10-day cycle were compared to determine if preferential depletion of one form between days 1 and 5 lead to compensatory depletion of the other form between days 5 and 10. This partitioning revealed no preferential uptake of either form of $\mathrm{N}$ at any time during this period (Table 3 ).

Nitrogen assimilation. Percent $\mathrm{NH}_{4}$ in roots for all cultivars declined between days 10 and 30 then increased from days 30 to 90 (Fig. 3A). Percent $\mathrm{NO}_{3}$ in roots was variable by cultivar at day 10 , but values for all cultivars were equal at day 20 and then followed similar patterns through day 90 (Fig. 3B). From day 30 to 60 , root $\mathrm{NO}_{3}$ levels declined two- to fivefold, depending on cultivar. From day 60 through day 90, root $\mathrm{NO}_{3}$ levels tended to increase slightly in 'Sequoia' and 'Sequest' but remained constant in 'Iridon'. The greatest similarities among cultivars for root $\mathrm{NO}_{3}$ occurred on days 30 and 90 ; however, on day 30 the level was 2.5 times that on day 90 . Shoot $\mathrm{NH}_{4}$ tended to increase slowly throughout development in 'Sequoia' and 'Sequest' but remained unchanged in 'Iridon', except for an increase by day 90 (Fig. 3C). In 'Sequoia' and 'Sequest', shoot $\mathrm{NO}_{3}$ increased from days 10 to 30 , then decreased until day 60 , and remained mostly unchanged through day 90 (Fig. 3D). Shoot $\mathrm{NO}_{3}$ in 'Iridon' was nearly constant from days 10 through 50 , then declined by day 60 to a level that was maintained through day 90. Ammonium and $\mathrm{NO}_{3}$ concentrations in roots tended to be higher in 'Iridon' than in 'Sequoia' and 'Sequest' (Fig. $3 \mathrm{~A}$ and B), whereas $\mathrm{NH}_{4}$ and $\mathrm{NO}_{3}$ concentrations in shoots tended to be lower in 'Iridon' than in 'Sequoia' and 'Sequest' (Fig. $3 \mathrm{C}$ and D).

Total $N$. Tissue N in 'Sequoia' (Fig. 4) was initially $1.3 \%$ of shoot dry weight and $6.4 \%$ of root dry weight. At day 30, shoot $\mathrm{N}$ had increased to $5.2 \%$, and root $\mathrm{N}$ had decreased to $5.5 \%$. Thereafter, root and shoot total $\mathrm{N}$ levels were similar, tending to decline slightly, with final levels (day 90) of $4.3 \%$ and $4.8 \%$ for shoot and root tissue, respectively.

\section{Discussion}

Ammonium and $\mathrm{NO}_{3}$ removal from hydroponic solutions (on a whole-plant basis) was greatest between days 40 and 50, with rapid reductions in $\mathrm{N}$ requirements after inflorescence buds had reached $1.0 \mathrm{~cm}$ in diameter (Fig. $2 \mathrm{~A}$ and B). Ammonium and $\mathrm{NO}_{3}$ removal (in milligrams per gram dry weight) was greatest on day 10 , then decreased by 20 to 25-fold during the 90 days of plant growth in this experiment (Fig. $2 \mathrm{C}$ and D). This decline suggests a high cellular requirement (in milligrams per gram dry weight) for $\mathrm{N}$ early in development. Total $\mathrm{N}$ was about 6 times less in shoots than in roots at the outset, but shoot $\mathrm{N}$ increased rapidly to a level similar to that in roots and remained mostly unchanged from days 30 through 90 (Fig. 4). Perhaps the physiological need for $\mathrm{N}$ was greatest early in the plant's growth cycle due to $\mathrm{N}$ deficiencies in cuttings that were rooted under a deionizedwater mist, requirements associated with ad-
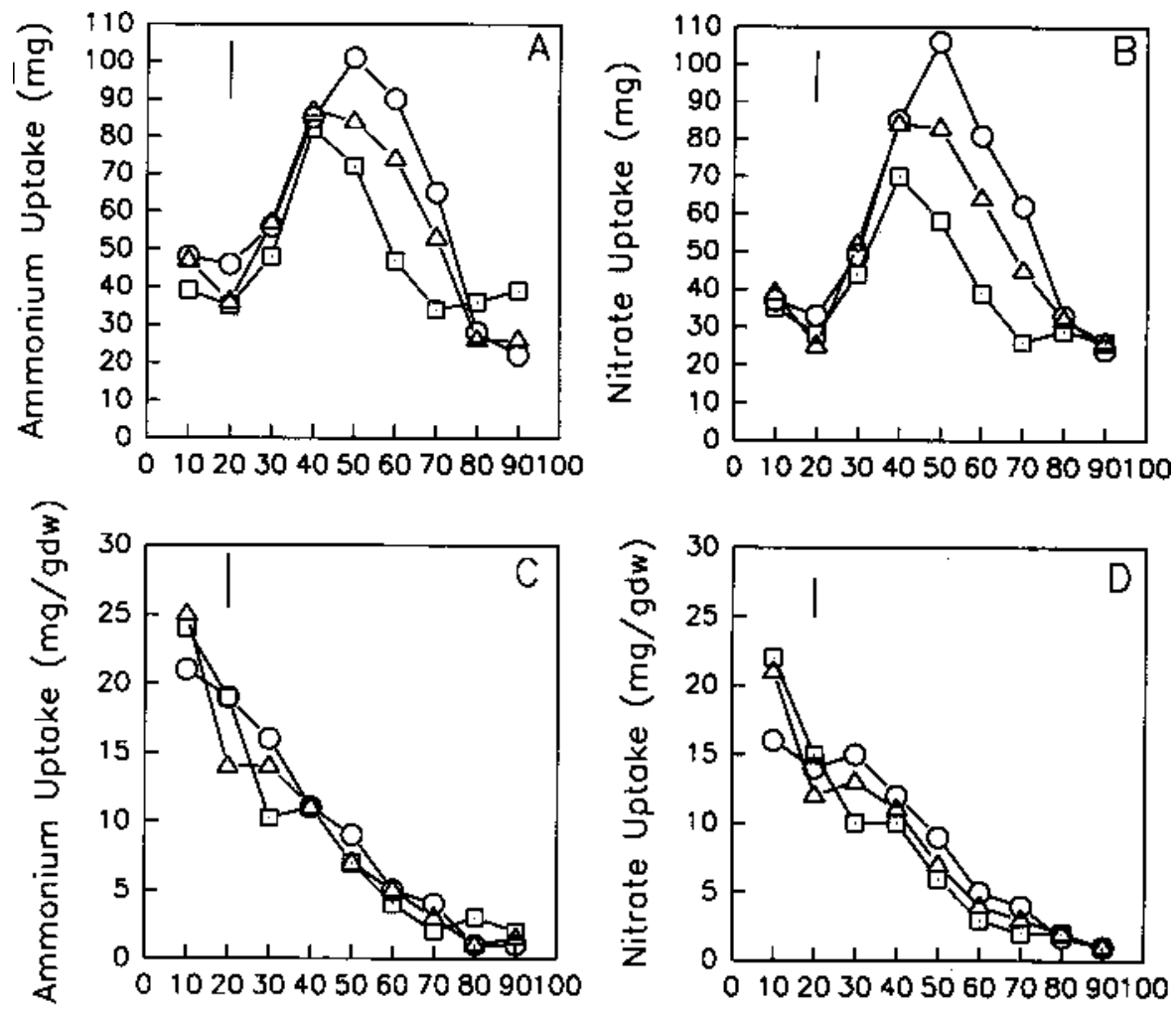

\section{Harvest Day}

Fig. 2. (A and C) Ammonium and (B and $\mathbf{D}) \mathrm{NO}_{3}$ removal from hydroponic solutions containing $1 \mathrm{~mm}$ (112 $\mathrm{mg}$ ) each of $\mathrm{NH}_{4}$ and $\mathrm{NO}_{3}-\mathrm{N}$ expressed in (A and $\left.\mathbf{B}\right)$ milligrams and $(\mathbf{C}$ and $\mathbf{D})$ milligrams per gram of tissue dry weight of Dendranthema $\times$ grandiflorum $(\square)$ 'Iridon', (O) 'Sequoia', and $(\Delta)$ 'Sequest'. Vertical bars indicate least significant difference at $P \leq 0.05$. 
centage of $\mathrm{NO}_{3}$ (Fig. 3B) either increased or was stable, depending on cultivar. Also, between days 10 and 30, shoot $\mathrm{NH}_{4}$ (Fig. 3C) remained nearly constant in all cultivars, but shoot $\mathrm{NO}_{3}$ accumulated in 'Sequoia' and 'Sequest' and was stable in 'Iridon' (Fig. 3D). During this period, total $\mathrm{N}$ increased in shoots and decreased in roots of 'Sequoia' (Fig. 4).

Nitrate assimilation requires reduced ferredoxin and, therefore, can compete with $\mathrm{CO}_{2}$ for light-derived chemical energy; $\mathrm{NH}_{4}$ assimilation is carbohydrate dependent (Hageman, 1984). During the first 30 days of development, photosynthetic shoot tissue was limited (Fig. 1B). Therefore, decreasing $\mathrm{NO}_{3}$ reduction and favoring $\mathrm{NH}_{4}$ as a $\mathrm{N}$ source may have been more energy efficient and provided a means of keeping $\mathrm{NH}_{4}$ concentrations below toxic levels. An alternative to this possibility is presented by Elliott and Nelson (1983), who calculated that the energy saved by restricted $\mathrm{NO}_{3}$ reduction would be insignificant and that under adequate light intensities, $\mathrm{NO}_{3}$ reduction likely would not compete with $\mathrm{CO}_{2}$ reduction. They hypothesized that assimilation of $\mathrm{NH}_{4}$ may satisfy a critical need for organic $\mathrm{N}$ in young, rapidly growing meristems that lack carbon skeletons and reductant for $\mathrm{NO}_{3}$ assimilation.

Nitrate accumulation suggests low $\mathrm{NO}_{3}$ reductase activity in the first 30 days of growth. We did not assay $\mathrm{NO}_{3}$ reductase activity, but our data are difficult to reconcile with previous reports of high $\mathrm{NO}_{3}$ reductase activity during this period (Woodson et al., 1984). High $\mathrm{NO}_{3}$ reductase activity might be expected if previous findings were based on plants supplied with only $\mathrm{NO}_{3}-\mathrm{N}$.

On a whole-plant basis, the period of greatest $\mathrm{N}$ demand [days 30 to 60 (Fig. $2 \mathrm{~A}$ and B)] corresponded to a time of rapid shoot growth and early inflorescence development. Comparing inflorescence diameter (Fig. 1E) with $\mathrm{N}$ uptake shows that rapid declines in uptake began when the diameter was $1.0 \mathrm{~cm}$. These events occurred near day 40 for 'Iridon' and day 50 for 'Sequoia' and 'Sequest': an expression of genotypic differences of the 9- and 10week response groups, respectively. Our data support Lunt and Kofranek (1958), who suggested terminating $\mathrm{N}$ applications when inflorescence buds are 1.0 to $1.5 \mathrm{~cm}$ wide.

Patterns of $\mathrm{N}$ removal from solutions (Fig. 2) and $\mathrm{N}$ assimilation (Fig. 3) for the three cultivars were similar; however, cultivars differed in their magnitudes of assimilation. For $\operatorname{root} \mathrm{NH}_{4}$, shoot $\mathrm{NH}_{4}$, and shoot $\mathrm{NO}_{3}$, 'Iridon' was distinct from 'Sequoia' and 'Sequest' (Fig. 3 A, C, and D). Generally, 'Iridon' tended to partition more of $\mathrm{NH}_{4}$ and $\mathrm{NO}_{3}$ into root tissue, whereas 'Sequoia' and 'Sequest' tended to partition these into shoot tissue. Clustering of data points for 'Sequoia' and 'Sequest' reflects their close genetic relationship, because 'Sequest' was selected as a sport from 'Sequoia'. Our data suggest that, in chrysanthemum, a genotypic effect in assimilating and partitioning $\mathrm{N}$ exists that could be manifested phenotypically as $\mathrm{N}$ efficiency. Nitrogen uptake per milligram of plant dry weight was similar for the three cultivars tested (Table
1), suggesting equal requirements at a cellular level. However, because 'Iridon' is an earlier genotype, it required less total $\mathrm{N}$ to complete its life cycle, therefore attaining $\mathrm{N}$ efficiency temporally. Genotypes with increased efficiency of $\mathrm{N}$ use have been described in Zea mays L. (Harvey, 1939) and in Lycopersicon esculentum Mill. (O'Sullivan, et al., 1974), where the trait is controlled by relatively few major genes with dominance and additive $x$ additive gene actions. Although not expressed as efficiency of $\mathrm{N}$ use, large differences in uptake of $\mathrm{NH}_{4}$ and $\mathrm{NO}_{3}$ occurred throughout development among four cultivars of Antirrhinum majus L. (Hood et al., 1993). These findings suggest the possibility of finding more extreme variation for $\mathrm{N}$ requirements by screening wider ranges of chrysanthemum germplasm than we used.

In this experiment, the plants demonstrated dramatic developmental changes around day 30. This was the first harvest day on which flower buds were visible (Fig. 1E). Also at this time, total $\mathrm{N}$ in 'Sequoia' roots and shoots

Table 3. Ammonium or $\mathrm{NO}_{3}-\mathrm{N}$ removed from solutions by Dendranthema xgrandiflorum 'Iridon', 'Sequoia', and 'Sequest' during the first 5 and second 5 days of 10-day harvest cycles. Values are means $\pm \mathrm{SE}$ of nine harvest cycles.

\begin{tabular}{lccccc}
\hline \hline & \multicolumn{2}{c}{ Uptake for days 1 to $5(\mathrm{mg})$} & & \multicolumn{2}{c}{ Uptake for days 6 to $10(\mathrm{mg})$} \\
\cline { 2 - 3 } \cline { 6 - 6 } Cultivar & $\mathrm{NH}_{4}$ & $\mathrm{NO}_{3}$ & & $\mathrm{NH}_{4}$ & $\mathrm{NO}_{3}$ \\
\hline Iridon & $23.4 \pm 2.8$ & $19.2 \pm 2.6$ & & $24.7 \pm 3.3$ & $20.7 \pm 6.3$ \\
Sequoia & $28.3 \pm 3.8$ & $26.6 \pm 4.5$ & & $34.2 \pm 5.7$ & $31.6 \pm 5.3$ \\
Sequest & $24.5 \pm 3.3$ & $23.0 \pm 3.5$ & & $30.8 \pm 4.9$ & $27.5 \pm 4.2$ \\
\hline
\end{tabular}
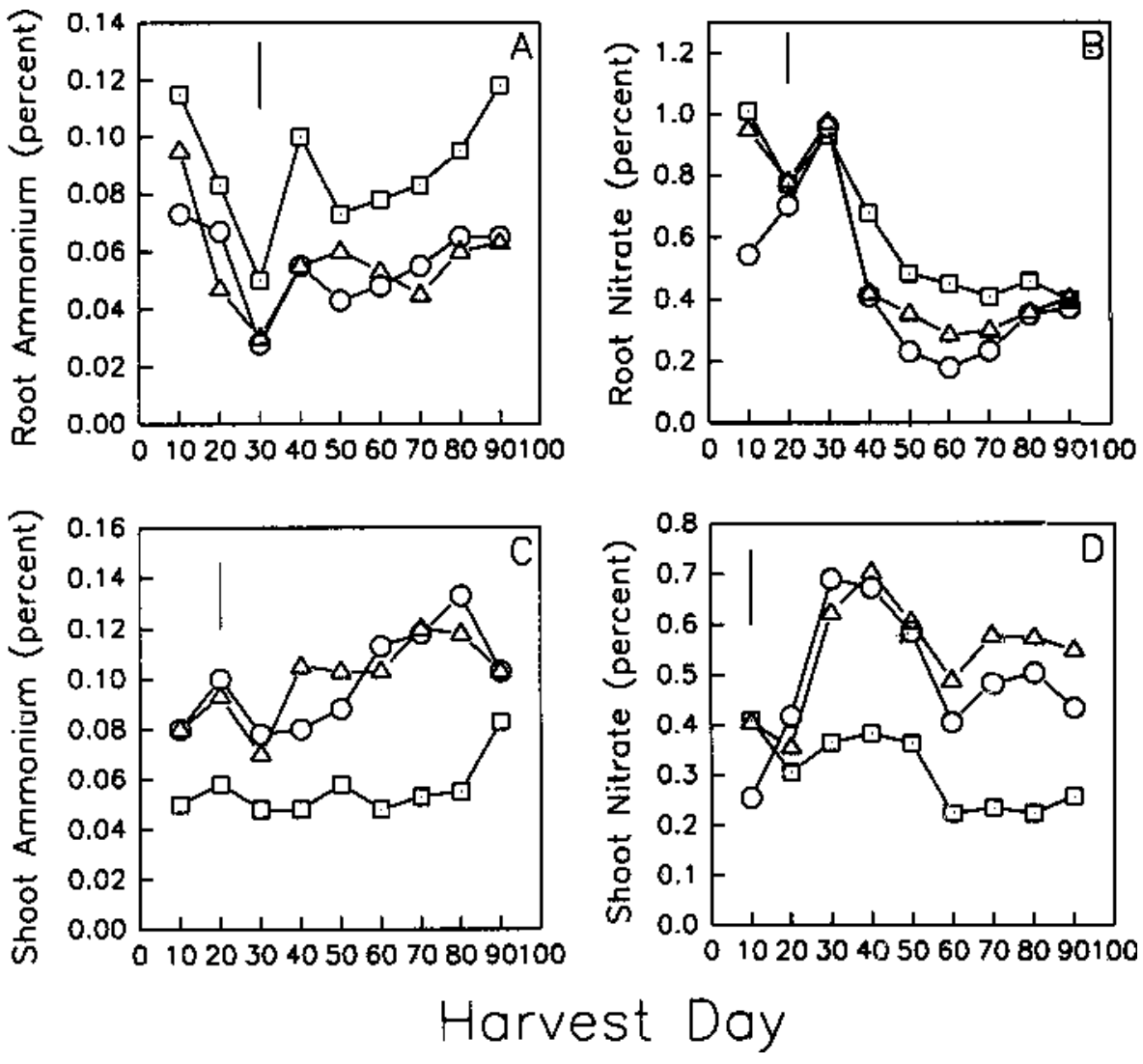

Fig. 3. Percentage of (A and $\mathbf{C}) \mathrm{NH}_{4}$ and $(\mathbf{B}$ and $\mathbf{D}) \mathrm{NO}_{3}$ in $(\mathbf{A}$ and $\mathbf{B})$ roots and $(\mathbf{C}$ and $\mathbf{D})$ shoots of Dendranthema $\times$ grandiflorum $(\square)$ 'Iridon', $(\bigcirc)$ 'Sequoia', and $(\Delta)$ 'Sequest' grown in hydroponic solution with $1 \mathrm{~mm}$ each of $\mathrm{NH}_{4}$ and $\mathrm{NO}_{3}-\mathrm{N}$. Vertical bars indicate least significant difference at $P \leq 0.05$. 


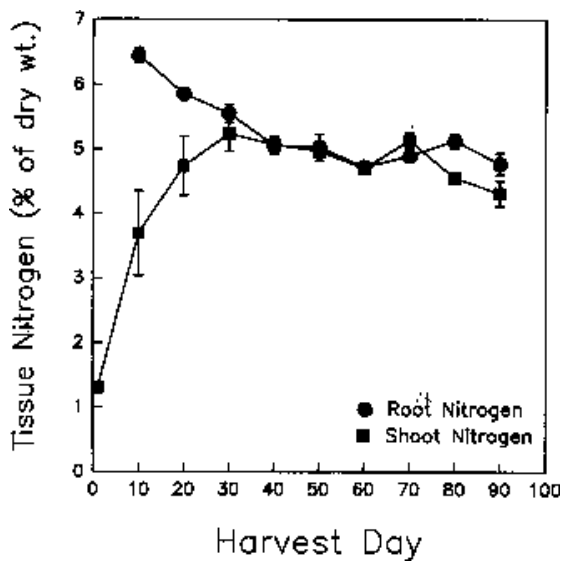

Fig. 4. Total $\mathrm{N}$ in $(\mathbf{O})$ roots and ( $\mathbf{\square})$ shoots of Dendranthema $\times$ grandiflorum 'Sequoia' grown in hydroponic solution containing $1 \mathrm{~mm}$ each of $\mathrm{NH}_{4}$ and $\mathrm{NO}_{3}-\mathrm{N}$. Vertical bars indicate \pm SE.

uptake and tissue levels of $\mathrm{NH}_{4}$ and $\mathrm{NO}_{3}-\mathrm{N}$ during all stages of growth from newly rooted cuttings to plants with fully developed inflorescences. This information should assist growers in matching $\mathrm{N}$ applications with a crop's developmentally dependent requirements and apprise plant breeders of genetic variation available in chrysanthemum to develop more $\mathrm{N}$-efficient cultivars.

\section{Literature Cited}

Boodley, J.W. and M. Meyer. 1965. The nutrient content of 'Bonnaffon Deluxe' chrysanthemum from juvenile to mature growth. Proc. Amer. Soc. Hort. Sci. 87:472-478.

Bremmer, J.M. 1965. Total nitrogen, p. 1149-1177. In: C.A. Black (ed.). Methods of soil analysis: Part 2: Chemical and microbiological properties. Amer. Soc. Agron., Madison, Wis.

Dole, J.M. and H.F. Wilkins. 1988. University of Minnesota tissue analysis standards. Dept. of Hort. Sci. and Landscape Arch., Univ. of Minnesota, St. Paul.

Elliott, G.C. and P.V. Nelson. 1983. Relationships among nitrogen accumulation, nitrogen assimilation and plant growth in chrysanthemums. Physiol. Plant. 57:250-259.

Hageman, R.H. 1984. Ammonium versus nitrate nutrition of higher plants, p. 67-86. In: R.D. Hauck (ed.). Nitrogen in crop production. Amer. Soc. Agron., Madison, Wis

Harvey, P.H. 1939. Hereditary variation in plant nutrition. Genetics 24:437-461.

Hoagland, D.R. and D.I. Arnon. 1950. The waterculture method for growing plants without soil. California Agr. Expt. Sta. Circ. 347.

Hood, T.M., H.A. Mills, and P.A. Thomas. 1993. Developmental stage affects nutrient uptake by four snapdragon cultivars. HortScience 28:10081010.

Keeney, D.R. and D.W. Nelson. 1982. NitrogenIn organic forms, p. 643-689. In: A.L. Page (ed.). Methods of soil analysis: Part 2: Chemical and microbiological properties. 2nd ed. Amer. Soc. Agron., Madison, Wis.

Kofranek, A. 1992. Cut chrysanthemums, p. 3-42. In: R.A. Larson (ed.). Introduction to floriculture. 2nd ed. Academic, New York.

Lunt, O.R. and A.M. Kofranek. 1958. Nitrogen and potassium nutrition of chrysanthemum. Proc. Amer. Soc. Hort. Sci. 72:487-497.

Nell, T., J.E. Barrett, and R.T. Leonard. 1989. Fertilization termination influences postharvest performance of pot chrysanthemum. HortScience 24:996-998.

Olsen, C. 1927. On the determination of nitrogen in soils. With special reference to the presence of nitrates and nitrites. Comptes-rendus des travaux du Laboratoire Carlsberg. vol 17, no. 3.

O'Sullivan, J., W.H. Gabelman, and G.C. Gerloff. 1974. Variations in efficiency of nitrogen utilization in tomatoes (Lycopersicon esculentum Mill.) grown under nitrogen stress. J. Amer. Soc. Hort. Sci. 99:543-547.

Willits, D.H., P.V. Nelson, M.M. Peet, M.A. Depa, and J.S. Kuehny. 1992. Modeling nutrient uptake in chrysanthemum as a function of growth rate. J. Amer. Soc. Hort. Sci. 117:769-774.

Woodson, W.R. and J.W. Boodley. 1983. Accumulation and partitioning of nitrogen and dry matter during the growth of chrysanthemum. HortScience 18:196-197.

Woodson, W.R., F.B. Negm, and J.W. Boodley. 1984. Relationship between nitrate reductase activity, nitrogen accumulation, and nitrogen partitioning in chrysanthemum. J. Amer. Soc. Hort. Sci. 109:491-494. 